Jurnal Perikanan (2019) Volume 9. No. 2 : 112-124

DOI : https://doi.org/10.29303/jp.v9i2.147

\title{
SUBSTITUSI DOSIS TEPUNG IKAN DENGAN MENGGUNAKAN TEPUNG KEPALA UDANG PADA PAKAN IKAN NILA (Oreochromis niloticus)
}

\section{SUBSTITUTION OF FISH MEAL DOSES BY USING SHRIMP HEAD FLOUR ON TILAPIA FEED (Oreochromis niloticus)}

\author{
Ninda Nastiti ${ }^{1 *}$, Nurliah ${ }^{1)}$, Bagus Dwi Hari Setyono ${ }^{1)}$. \\ 1)Program Studi Budidaya Perairan, Fakultas Pertanian, Universitas Mataram
}

\begin{abstract}
Abstrak
Penelitian ini bertujuan untuk mengetahui pengaruh pemanfaatan tepung kepala udang sebagai bahan substitusi dosis tepung ikan pada pakan ikan Nila (Oreochromis niloticus) serta mengetahui dosis tepung kepala udang yang optimal untuk pertumbuhan ikan Nila. Penelitian ini dilaksanakan pada tanggal 16 Desember sampai dengan 8 Pebruari dengan masa pemeliharaan selama 45 hari bertempat di Laboratorium Program Studi Budidaya Perairan, Fakultas Pertanian, Universitas Mataram. Penelitian ini menggunakan metode eksperimental dengan Rancangan Acak Lengkap (RAL) dengan 4 perlakuan dan 5 ulangan, yaitu : (kontrol) pakan komersil, (P1) 0\% tepung kepala udang, (P2) 20\% tepung kepala udang, dan (P3) 35\% tepung kepala udang. Data perhitungan dianalisis menggunakan ANOVA dengan tingkat kepercayaan $95 \%$. Hasil perhitungan menunjukkan bahwa jenis pakan yang berbeda tidak berpengaruh nyata terhadap laju pertumbuhan mutlak, laju pertumbuhan spesifik, rasio konversi pakan, tingkat kelangsungan hidup, dan efisiensi pakan pada ikan Nila. Penggunaan tepung kepala udang pada pakan mampu memberikan pertumbuhan yang sama baiknya dengan pakan komersil maupun pakan tanpa penambahan tepung kepala udang serta mampu menekan biaya produksi pada pembuatan pakan.
\end{abstract}

Kata kunci : Tepung kepala udang, pertumbuhan, substitusi, ikan Nila.

\begin{abstract}
This study aims to determine the effect of the use of shrimp head flour as a substitution material for fish meal doses on tilapia feed (Oreochromis niloticus) and to determine the optimal dose of shrimp head meal for the growth of tilapia. This research was conducted on December 16 to February 8 with a maintenance period of 45 days at the Laboratory of Aquaculture Study Program, Faculty of Agriculture, University of Mataram. This study used an experimental method with Completely Randomized Design (CRD) with 4 treatments and 5 replications : (control) commercial feed, (P1) 0\% shrimp head flour, (P2) 20\% shrimp head flour, and (P3) $35 \%$ shrimp head flour. Calculation data were analyzed using ANOVA with a confidence level of $95 \%$. The calculation results show that different types of feed do not significantly influence the absolute growth rate, specific growth rate, feed conversion ratio, survival rate, and feed efficiency in tilapia. The use of shrimp head flour in feed is able to provide growth as well as commercial and feed feed without the addition of shrimp head flour and can reduce production costs in the manufacture of feed.
\end{abstract}

Keywords: Shrimp head flour, growth, dose substitution, Tilapia.

*Korespondensi :

adhitadama@gmail.com 


\section{Pendahuluan}

Ikan Nila (Oreochromis niloticus) merupakan salah satu komoditas perikanan yang memiliki prospek yang cukup baik.Ikan nila memiliki beberapa keunggulan dibandingkan dengan ikan tawar jenis lainnya, yaitu mudah dibudidayakan, memiliki daging yang tebal, dan kandungan duri yang sedikit sehingga dapat diolah menjadi berbagai macam olahan.Ditinjau dari kebiasaan makannya, ikan Nila adalah ikan pemakan segala (omnivora) sehingga mudah untuk diberikan pakan tambahannya.Menurut Suyanto (2005) dalam Satia et al (2011) ikan nila tahan terhadap lingkungan, bersifat omnivora, mampu mencerna makanan secara efisien, pertumbuhan cepat dan tahan terhadap hama penyakit.

Keberhasilan budidaya ikan ditentukan oleh beberapa faktor, salah satunyaadalah ketersediaan pakan yang berkualitas.Pada industri perikananbudidaya, pakan memegang peranan sangat besar, karena hampir 60$80 \%$ biayaproduksi berasal dari pakan.Menurut Afrianto dan Liviawati (2005) usaha budidaya ikan sangat dipengaruhi oleh ketersediaan pakan yang cukup dalam jumlah dan kualitasnya untuk mendukung pertumbuhan yang maksimal.Budidaya perikanan yang intensif sangat menuntuttersedianya pakan dalam kualitas yang baik, kuantitas yang cukup, harga yang murah, tepat waktu dan berkesinambungan.Oleh karena itu dalam pembuatan pakan perlu disusun komposisinya dengan baik. Persyaratan pakan buatan untuk ikan antara lain memiliki aroma yang disukai ikan, warna yang dapat menarik perhatian ikan, tidak mengandung racun dan memenuhi nilai gizi yang diperlukan tubuh seperti protein, lemak, karbohidrat, vitamin dan mineral. Usaha budidaya perikanan diIndonesia menghadapi permasalahan yang berat dengan naiknya harga pakan ikan karena naiknya harga bahan baku impor. Hal ini dapatmengakibatkan keuntungan yang diperoleh pembudidaya ikan menjadi rendah. Keuntungan yang rendah akan mempengaruhi keberlanjutan usaha budidaya.Salah satu bahan baku pakan yang masih impor dengan harga tinggi adalah tepungikan.Data yang didapatkan dari Badan Pusat Statistik (2010) bahwa Indonesiamengimpor tepung ikan sebesar 65.601 ton pada tahun 2009.

Tepung ikan merupakan bahan baku pakan yang penting karena proteinnya tinggi dan mengandung mineral serta vitamin, namun seiring meningkatnya kebutuhan tepung ikan membuat harga tepung ikan kian meningkat dan secara berkala akan mengakibatkan over fishing atau berkurangnya stok ikan di perairan umum demi berlangsungnya budidaya. Salah satu cara untuk mengatasi permasalahan tersebut adalah dengan mensubtitusi dosis tepung ikan dengan sumber protein lain yang lebih murah, mudah didapat, dan berkualitas baik. Pakan alternatif yangdiberikan pada ikan hendaknya bermutu baik sesuai dengan kebutuhan ikan,tersedia setiap saat, dan harganya murah (Suprayudi, 2010).Bahan pakan alternatif yang dapat digunakan sebagai substitusi dosis tepung ikan dengan menggunakan tepung kepala udang.

Indonesia merupakan salah satu negara pengekspor udang terbesar di dunia dengan angka permintaan pasar yang tinggi.Data BPS tahun2010 menunjukkan produksi udang Indonesia sebesar 338.060 ton pada tahun2009 dan 352.600 ton pada tahun 2010 (BPS, 2010). Apabila udang segar ini diolah menjadiudang beku, maka sebesar 35-40\% dari bobot utuh akan menjadi limbah udang,kualitasnya bervariasi tergantung jenis udang dan proses pengolahannya (Abun, 2009). 
Ekspor udang dapat berupa udang tidak beku, udang beku dan udangdalam kaleng. Produk udang beku sebagian besar berupa produk tanpa kepala(headless) dan produk udang kupasan (peeled). Bagian udang yang terbuang tersebut ada bagian yang masih layak bagi konsumsi, misalnya bagian kepala dandada udang (cephalothorax).Kepala udang sangat potensial dijadikan bahanpakan sumber protein hewani karena ketersediaannya cukup banyak danmengandung zat-zat gizi yang tinggi.Menurut Laining et al(2003), nilai protein ini cukup tinggi sehingga dapat dijadikan bahan alternatif sumber protein pada pakan ikan.Penelitian tentang pemanfaatan tepung kepala udang pada pakan telah dilakukan beberapa diantaranya dalam pakan ternak ayam maupun ikan, namun penggunaannya masih sedikit. Menurut Hetramf dan Piedad-Pscual (2000) dalam Retno (2012) melaporkan bahwa berdasarkan komposisi bahan kering, kepala udang mengandung 43,2 \% protein kasar; 5,6 \% lemak; 15,8 \% serat kasar; 33,0 \% abu; dan 2,4 BETN. Hasil riset Mukti (2012) yang telah melakukan penelitian menggunakan tepung kepala udang melaporkan bahwa laju pertumbuhan tertinggi pada ikan patin terdapatpada pakan dengan dosis $30 \%$ TKU.Sedangkan menurut Jatomea et al. (2002) mengatakan bahwa penambahan tepung kepala udang sebesar $15 \%$ dalam pakan dapat meningkatkan pertumbuhan ikan nila (Oreochromis niloticus). Hasil riset lain dari Ceballos et al (2009) menyatakan bahwa penambahan tepung kepala udang sampai dosis $25 \%$ masih memberikan hasil yang signifikan. Berdasarkan uraian diatas, untuk mensubtitusi dosis tepung ikan sebagai bahan bakupakan ikan maka perlu dilakukan penelitian tentang Substitusi Dosis Tepung Ikan Dengan Menggunakan
Tepung Kepala Udang Pada Pakan Ikan Nila (Oreochromis niloticus).

\section{Metode}

\section{Waktu dan Tempat}

Penelitian ini telah dilaksanakan pada tanggal 16 Desember 2018 sampai dengan 8Pebruari 2019 dengan masa pemeliharaan ikan selama 45 hari. Lokasi penelitian ini bertempat di Laboratorium Program Studi Budidaya Perairan, Universitas Mataram.

\section{Alat-alat Penelitian}

Adapun alat yang digunakan yaitu, aquarium, aerasi, timbangan, penggaris, thermometer, DO meter, $\mathrm{pH}$ meter, alat pencetak, penggiling, nampan, oven, ayakan, panci, kompor, toples kecil, kain halus, alat tulis, laptop, dan kamera.

\section{Bahan-bahan Penelitian}

Adapun bahan yang digunakan yaitu, tepung kepala udang, tepung ikan, minyak ikan, tepung tapioka, tepung jagung, dedak halus, putih telur, air, pakan komersil Hi-ProVit, dan tissue.

\section{Metode Penelitian}

Penelitian ini dilaksanakan dengan metode eksperimental dan dirancang menggunakan rancangan acak lengkap dengan 4 perlakuan dan 5 kali ulangan dengan setiap perlakuan sebagai berikut :

$$
\begin{array}{ll}
\text { Kontrol } & =\text { Pakan komersil Hi- } \\
& \text { ProVit protein 31-33\% } \\
\text { Perlakuan 1 } & =0 \% \text { tepung kepala } \\
& \text { udang } \\
\text { Perlakuan 2 } & =20 \% \text { tepung kepala } \\
& \text { udang } \\
\text { Perlakuan 3 } & =35 \% \text { tepung kepala udang }
\end{array}
$$

\section{Prosedur penelitian}

1. Pakan Uji

Persiapan bahan berupa tepung kepala udang dimulai dengan dicuci kepala 
udang hingga bersih, penjemuran kepala udang dibawah sinar matahari langsung selama 4 hari dan dioven untuk menekan kadar air yang ada dalam kepala udang. Kepala udang yang sudah kering dihaluskan dan diayak dengan 3 kali pengayakan ulang agar mendapatkan tepung kepala udang yang halus dan mengurangi kandungan kitin di dalam tepung kepala udang dan dilakukan analisis proksimat terhadap tepung kepala udang. Disiapkan juga bahan baku pembuatan pakan yang lainnya berupa tepung jagung, tepung ikan, tepung tapioka, dedak halus, dan minyak ikan.

Proses pembuatan pakan diawali dengan menimbang jumlah bahan pada masingmasing perlakuan dan ditempatkan dalam wadah tersendiri. Bahan dicampurkan satu per satu yang dituang dalam satu wadah dengan bahan yang memiliki porsi lebih sedikit dan disusul dengan bahan baku dengan porsi yang lebih banyak agar bahan dapat tercampur merata. Setelah bahan tercampur merata, ditambahkan air hangat dan diaduk merata kembali sampai pakan berbentuk seperti pasta kemudian pakan digumpal-gumpalkan dan dikukus selama 10 menit agar mudah dibentuk atau dicetak. Pakan dimasukkan ke dalam cetakan manual dan ditampung di atas wadah nampan dan dipilah agar tidak menumpuk yang akan menyebabkan pakan berjamur. Pakan yang telah tercetak kemudian dijemur di bawah sinar matahari langsung selama 3 hari dan dilakukan penyemprotan menggunakan putih telur sebagai pelapis agar pakan tidak mudah hancur didalam air.Pakan dipotong-potong sesuai dengan bukaan mulut ikan.Setelah pakan jadi maka dilakukan analisis proksimat untuk mengetahui kandungan nutrisi pada masing-masing pakan.

\section{Pemeliharaan Ikan}

Ikan uji yang digunakan dalam penelitian ini adalah ikan Nila yang berasal dari Balai Benih Ikan Batu Kumbung (BBI Batu Kumbung), Lingsar.Ikan uji dibagi dalam 3 perlakuan, 1 kontrol dengan 5 kali ulangan. Jumlah ikan yang akan dipelihara sebanyak 10 ekor per aquarium dengan panjang 6-8 $\mathrm{cm}$ dan bobot \pm 4-8 gram.

Pakan yang diberikan sesuai dengan berat biomassa ikan yaitu 5\% dari bobot tubuh ikan.Frekuensi pemberian pakan dilakukan sebanyak 3 kali sehari yakni pada pukul 08:00, 13:00, dan 18:00 WITA.Mula-mula ikan diadaptasikan terhadap pakan selama 4 hari. Setelah masa adaptasi berakhir, ikan dipuasakan selama 24 jam untuk menghilangkan sisa pakan dalam saluran pencernaan ikan, kemudian ikan ditimbang bobot dan diukur panjang tubuhnya dan dimasukkan kembali ke dalam aquarium. Setelah masa adaptasi, ikan kemudian diberi perlakuan.Pemeliharaan dilakukan selama 45 hari. Sampling dilakukan setiap seminggu sekali dengan cara menghitung dan menimbang biomassa setengah dari total jumlah ikan per aquarium kemudian dicatat biomassanya untuk mendapatkan data SGR. Untuk mendapatkan berat dan panjang mutlak pengukuran dilakukan pada awal dan akhir.

pemeliharaan. Penyiponan dilakukan sebanyak satu atau dua kali sehari dengan mengamati jumlah feses ikan, serta dilakukan pergantian air sebanyak 50-70\% dari total media selama 4 hari sekali

\section{Pengambilan Data}

a. Pertumbuhan ikan

Sampling dilakukan pada hari ke 7 , 14, 21, 28, 35, 42, dan 45 setelah penebaran awal dan dilakukan sebelum pemberian pakan pada pagi hari. Sampling dilakukan dengan menggunakan timbangan digital untuk mengukur berat, dan menggunakan penggaris untuk mengukur panjang ikan. 


\section{b. Kualitas air}

Parameter kualitas air yang diukur meliputi suhu, DO, dan $\mathrm{pH}$. Pengukuran kualitas air dilakukan 7 hari sekali setelah pergantian air secara total.

c. Uji proksimat pakan

Uji kandungan nutrisi atau proksimat pada pakan dan tepung kepala udang dilakukan dengan menggunakan metode AOAC di Laboratorium Peternakan Universitas Mataram.

\section{Analisis Data}

\begin{tabular}{lr}
\multicolumn{1}{c}{ Data hasil } & perhitungan \\
dianalisismenggunakan & CoStat \\
untukpenyajian $\quad$ grafis. & Analisis \\
datadilakukan & menggunakan \\
ANOVAdengan tingkat kepercayaan $95 \%$.
\end{tabular}

\section{Hasil}

\section{Analisis Proksimat TKU}

Hasil analisis proksimat yang telah dilakukan terhadap tepung kepala udang didapatkan kandungan bahan yakni air sebesar 11,3254 \%; abu sebesar 36,0457 $\%$; lemak kasar sebesar $1,1272 \%$; serat kasar sebesar 14,5547 \%; dan protein kasar sebesar $19,0416 \%$.

\section{Laju Pertumbuhan Mutlak (LPM)}

Laju pertumbuhan mutlak adalah selisih berat total tubuh ikan pada akhir dan awal pemeliharaan. Peningkatan bobot pada semua perlakuan menjelaskan bahwa semua pakan perlakuan yang diberikan dapat memenuhi kebutuhan ikan Nila untuh tumbuh dan hidup.

Berdasarkan hasil penelitian yang telah dilaksanakan selama 45 hari, diketahui bahwa laju pertumbuhan mutlak ikan Nila selama pemeliharaan yang diberikan tepung kepala udang sebagai substitusi dosis tepung ikan berkisar yakni, pakan P2 (20\% TKU) sebesar 17,876 0,892 gram, dan pakan P3 (35 \% TKU) sebesar 16,516 $\pm 0,934$ gram dengan lama pemeliharaan 45 hari. Sedangkan laju pertumbuhan mutlak untuk pakan $\mathrm{K}$ (komersil) dan pakan P1 (0\% TKU) dengan kisaran nilai yakni 17,494 $\pm 2,337$ gram dan 17,96 $\pm 1,232$ gram dapat dilihat pada Gambar 3.

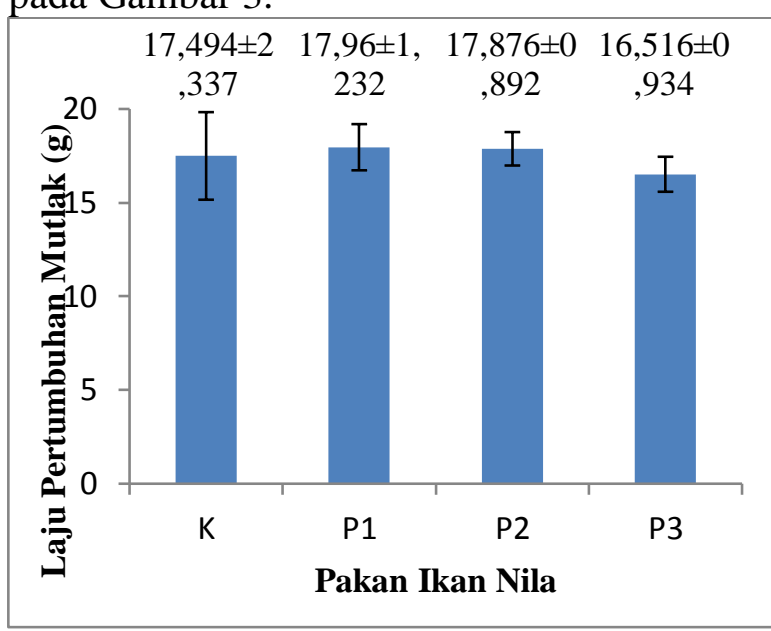

Gambar 3.Laju Pertumbuhan mutlak rata-rata ikan Nila dengan perlakuan $\mathrm{K}$ (pakan komersil), P1 (0\% TKU), P2 (20\% TKU), P3 (35\% TKU).

Data rata-rata laju pertumbuhan mutlak ikan Nila menunjukkan bahwa pada pakan P1 tanpa substitusi dosis tepung ikan menggunakan tepung kepala udang memiliki nilai rata-rata yang cenderung lebih tinggi dari yang lain. Akan tetapi dari hasil uji ANOVA diketahui bahwa jenis pakan tidak berpengaruh nyata terhadap laju pertumbuhan mutlak $(\mathrm{P}>0,05)$ pada Lampiran 8

\section{Laju Pertumbuhan Spesifik (LPS)}

Laju pertumbuhan spesifik merupakan laju pertumbuhan harian atau persentase penambahan bobot ikan setiap harinya.Perhitungan laju pertumbuhan spesifik dilakukan dengan menimbang bobot ikan pada setiap perlakuan setiap satu minggu sekali.Selama penelitian, ikan uji menunjukkan peningkatan bobot pada semua perlakuan.

Berdasarkan hasil penelitian selama 45 hari diketahui laju pertumbuhan 
spesifik ikan Nila dengan kisaran nilai rata-rata yakni 3,44 - 3,564\% perminggu. Pada Gambar 4 pakan K (komersil) yang menunjukkan laju pertumbuhan spesifik cenderung lebih tinggi dibandingkan pakan yang lain dengan nilai kisaran untuk pakan yang menggunakan tepung kepala udang sebagai substitusi dosis tepung ikan yakni, pakan P2 (20\% TKU) sebesar 3,44 $\pm 0,215$ $\%$ dan pakan P3 (35\% TKU) sebesar $3,457 \pm 0,246 \%$. Sedangkan untuk nilai laju pertumbuhan spesifik pada pakan $\mathrm{K}$ (komersil) yakni sebesar 3,564 $\pm 0,302 \%$

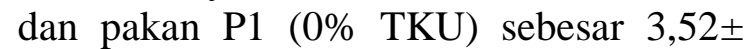
$0,161 \%$.

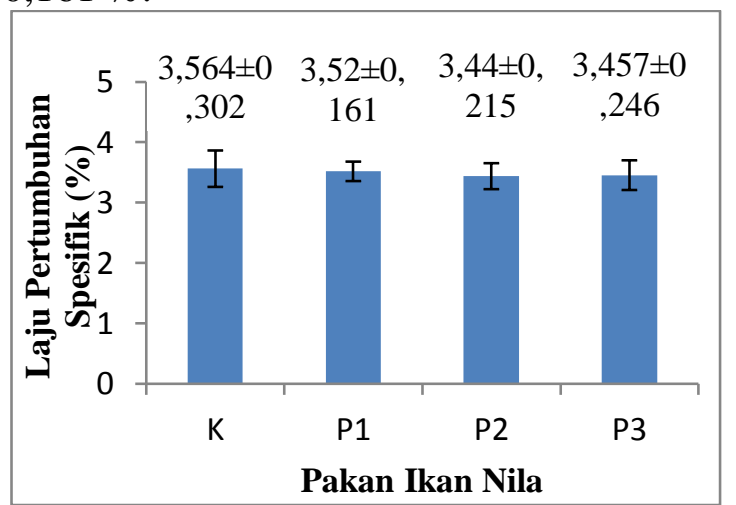

Gambar 4.Laju Pertumbuhan spesifik rata-rata ikan nila dengan perlakuan $\mathrm{K}$ (pakan komersil), P1 (0\% TKU), P2 (20\% TKU), P3 (35\% TKU).

Hasil uji ANOVA menunjukkan bahwa jenis pakan tidak berpengaruh nyata terhadap laju pertumbuhan spesifik ikan Nila $(\mathrm{P}>0,05)$. Hasil uji ANOVA dapat dilihat pada Lampiran 9.

\subsubsection{Kelangsungan Hidup}

Kelangsungan hidup/Survival Rateadalah persentase jumlah ikan yang hidup setelah dipelihara dibandingkan dengan jumlah ikan pada awal penebaran. Hasil penelitian selama 45 hari menunjukkan bahwa tingkat kelangsungan hidup ikan Nila yang diberi pakan dengan tepung kepala udang sebagai substitusi dosis tepung ikan yakni, pakan P2 (20\% TKU) sebesar $88 \pm 8,367 \%$; pakan P3
$(35 \%$ TKU) sebesar $94 \pm 8,944 \%$. Sedangkan nilai yang didapatkan pada ikan Nila yang diberikan pakan K (komersil) sebesar $92 \pm 8,367 \%$ dan pakan P1 $(0 \%$ TKU) sebesar $96 \pm 5,477 \%$. Dari nilai tersebut dapat dilihat bahwa tingkat kelangsungan hidup ikan Nila pada perlakuan P1 (0\% TKU) memiliki nilai yang cenderung lebih tinggi dibandingkan yang lain. Pada Gambar 5 berikut menyajikan kelangsungan hidup / survival rate (SR) rata-rata pada ikan nila yang dipelihara selama 45 hari.

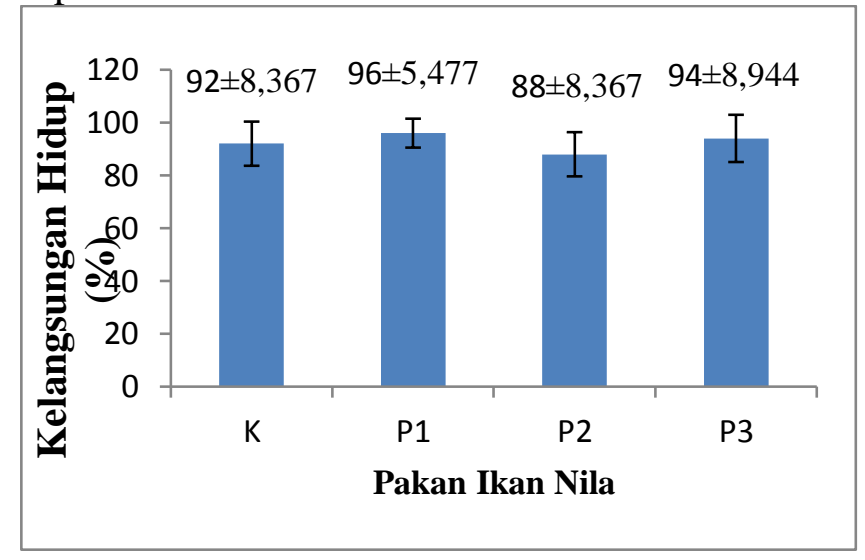

Gambar 5.Kelangsungan Hidup rata-rata ikan nila denganperlakuan $\mathrm{K}$ (pakan komersil), P1 (0\% TKU), P2 (20\% TKU), P3 (35\% TKU).

Hasil analisa ANOVA menunjukkan bahwa jenis pakan tidak berpengaruh nyata terhadap tingkat kelangsungan hidup ikan Nila $(\mathrm{P}>0,05)$. Hasil uji ANOVA dapat dilihat pada Lampiran 10.

\subsubsection{Rasio Konversi Pakan (FCR)}

FCR atau nilai konversi pakan menunjukkan seberapa besar pakan yang dikonsumsi menjadi biomassa tubuh ikan.Semakin rendahnya nilai rasio konversi pakan, maka semakin baik pakan tersebut.

Rasio konnversi pakan ikan Nila selama 45 hari yang diberikan tepung kepala udang sebagai substitusi dosis 
tepung ikan memiliki kisaran nilai yakni, pada pakan P2 (20\% TKU) sebesar 1,498 \pm $0,122 \%$ dan pakan P3 (35\% TKU) sebesar $1,348 \pm 0,054 \%$. Pada pakan tanpa pemberian tepung kepala udang yakni pakan $\mathrm{K}$ (komersil) memiliki nilai sebesar $1,444 \pm 0,166 \%$ dan pakan P1 (0\% TKU) sebesar $1,388 \pm 0,110 \%$. Nilai FCR yang cenderung lebih optimal terdapat pada pakan P3 (35\% TKU) dibandingkan dengan pakan yang lain dapat dilihat pada Gambar 6.

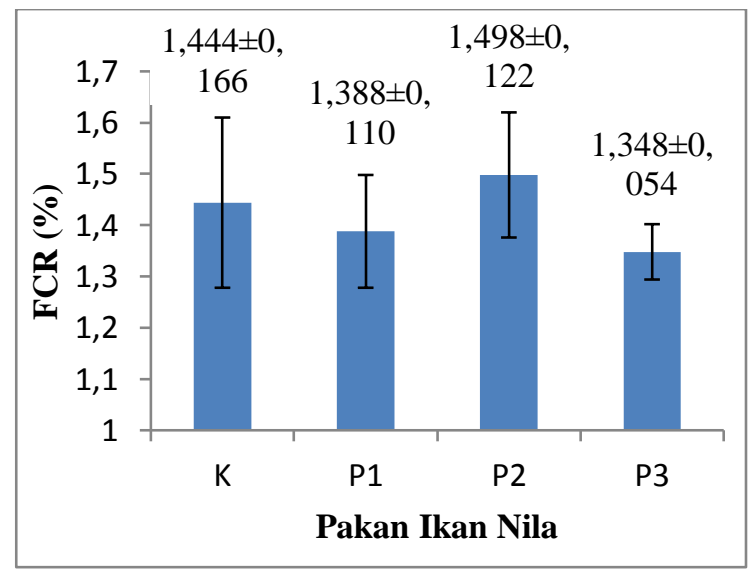

Gambar 6.Rasio Konversi Pakan (FCR) ratarata ikan nila dengan perlakuan $\mathrm{K}$ (pakan komersil), P1 (0\% TKU), P2 (20\% TKU), P3 (35\% TKU).

Setelah dilakukan uji ANOVA terhadap rasio konversi pakan (FCR) didapatkan hasil bahwa jenis pakan tidak berpengaruh nyata terhadap rasio konversi pakan ikan nila $(\mathrm{P}>0,05)$ yang dapat dilihat pada Lampiran 11.

\subsubsection{Efisiensi Pakan (EP)}

Efisiensi pakan merupakan kunci untuk profitabilitas dalam budidaya.Nilai efisiensi pakan diperoleh dari hasil perbandingan antara pertambahan bobot ikan dengan jumlah pakan yang dikonsumsi oleh ikan selama masa pemeliharaan.

Berdasarkan hasil penelitian diketahui bahwa nilai efisiensi pakan pada ikan nila yang diberikan pakan dengan menggunakan tepung kepala udang sebagai substitusi dosis tepung ikan memiliki kisaran nilai yaitu, pada pakan P2 $(20 \%$ TKU) sebesar 64,294 $\pm 6,863 \%$ dan pada pakan P3 (35\% TKU) sebesar 72,516 \pm $4,796 \%$. Sedangkan efisiensi pakan untuk kontrol dengan menggunakan pakan komersil dan tanpa penambahan tepung kepala udang yakni dengan nilai, pakan $\mathrm{K}$ (komersil) sebesar 66,718 \pm 7,522 \% dan pakan P1 (0\% TKU) sebesar 71,356 \pm $7,073 \%$, dimana nilai rata-rata untuk efisiensi pakan cenderung lebih optimal pada pakan P3 (35\% TKU) yakni dengan substitusi dosis tepung ikan menggunakan tepung kepala udang yang dapat dilihat pada Gambar 7.

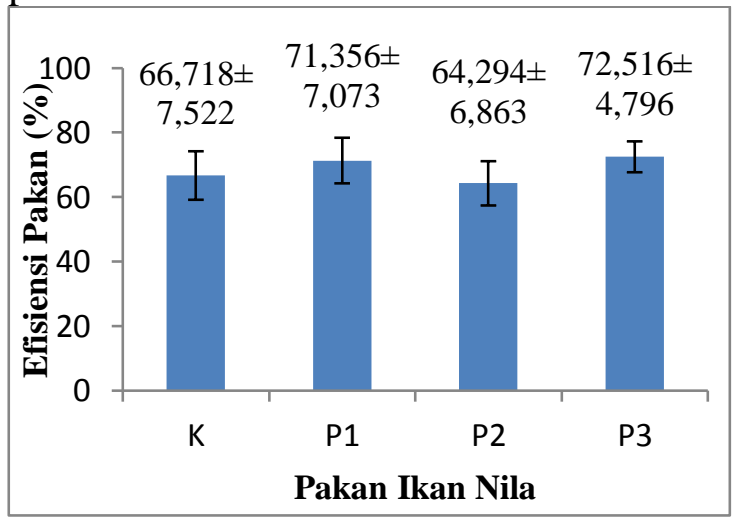

Gambar 7.Efisiensi pakan rata-rata ikan nila dengan perlakuan $\mathrm{K}$ (pakan komersil), P1 (0\% TKU), P2 (20\% TKU), P3 (35\% TKU).

Hasil uji ANOVA pada efisiensi pakan menunjukkan bahwa jenis pakan tidak berpengaruh nyata terhadap efisiensi pakan ikan Nila $(\mathrm{P}>0,05)$ yang dapat dilihat pada Lampiran 12.

\subsubsection{Kualitas Air}

Kualitas air yang baik akan mendukung pertumbuhan dan kelangsungan hidup biota. Hal ini berhubungan dengan faktor stress yang nantinya akan dialami oleh ikan jika kualitas air buruk. Kualitas air di dalam akuarium selama pemeliharaan terbilang 
baik dengan parameter antara lain suhu, $\mathrm{pH}$, dan $\mathrm{DO}$ yang memiliki kisaran sebagai berikut Tabel 4.

Tabel 4. Kualitas Air Pemeliharaan

\begin{tabular}{|c|c|c|c|c|}
\hline \multicolumn{3}{|c|}{ Parameter Satruan Hasil Pengamatan } & \multirow{2}{*}{$\begin{array}{c}\text { Stander Kualitas Air } \\
25-30\end{array}$} & \multirow{2}{*}{$\frac{\text { Reffi }}{\text { Ami, } 20}$} \\
\hline Suhu & $(C)$ & $289,-30,1$ & & \\
\hline $\mathrm{pH}$ & & $7,1-1,7,7$ & 5.9 & Amin, 20 \\
\hline DO & $(\mathrm{mgL})$ & $5-6,2$ & 5.7 & Amini 2l \\
\hline
\end{tabular}

\section{Pembahasan \\ Pertumbuhan}

Percobaan substitusi dosis tepung ikan dengan menggunakan tepung kepala udang pada pakan ikan Nila dengan perbandingan $0 \%, 20 \%$, dan $35 \%$ yang diberikan telah dilakukan selama 45 hari. Pengamatan dan pengukuran dilakukan untuk melihat dan mengetahui pengaruhnya terhadap pertumbuhan mutlak dan spesifik ikan nila telah dilakukan, dengan pakan komersil sebagai pakan kontrol.

Hasil uji ANOVA pada pertumbuhan mutlak dan spesifik menunjukkan bahwa jenis pakan tidak berpengaruh nyata terhadap laju pertumbuhan mutlak dan spesifik ikan Nila $(\mathrm{P}>0,05)$.Meskipun tidak berbeda nyata, namun masing-masing perlakuan memberikan pertumbuhan yang baik.

Pertumbuhan mutlak dan spesifik ikan nila tersebut dipengaruhi oleh kualitas dan kuantitas pakan, di mana salah satunya merupakan kandungan protein yang terdapat di dalam pakan yang diberikan, selain itu penggunaan tepung kepala udang juga mempengaruhi kecernaan protein pakan.Menurut Sukandi (2003) baik tidaknya suatu pakan ditentukan oleh kandungan nutrisinya, salah satu kebutuhhan nutrisi yang penting untuk ikan adalah protein.
Pertumbuhan ikan pada perlakuan pakan yang berbeda dikarenakan kandungan protein yang secara fluktuatif menurun ini ditunjang dari hasil analisis proksimat yang telah dilakukan pada Lampiran 7 dengan nilai protein pada masing-masing pakan yakni, pakan $\mathrm{K}$ (komersil) 31-33\%;pakan P1 (0\% TKU) 49,03\%; P2 (20\% TKU) 40,6383\%; dan pakan P3 (35\% TKU) sebesar 34,3446\%, dari nilai protein yang terdapat pada masing-masing pakan merupakan nilai protein yang dapat menunjang pertumbuhan ikan nila. Hal ini sesuai dengan pernyataan Iskandar dan Elrifadah (2015), untuk pemeliharaan ikan nila secara intensif maka dibutuhkan makanan tambahan berupa pelet.Pelet yang harus diberikan mengandung protein minimal 25\%.Ikan nila tumbuh lebih cepat meski hanya diberi pakan yang mengandung protein 20\%-25\%. Penurunan kadar protein pada pakan diduga karena adanya proses deaminasi atau reaksi kimia pada saat pengolahan bahan pakan. Ketersediaan dan jumlah protein pada pakan sangat mempengaruhi pertumbuhan ikan baik pertambahan bobot dan panjang ikan, dimana protein merupakan salah satu nutrisi yang sangat berpengaruh pada pertumbuhan ikan nila.Perbedaan nilai kandungan protein dapat mempengaruhi pertumbuhan, namun pada penelitian ini tidak ada perbedaan pertumbuhan karena nilai protein pada pakan perlakuan subtitusi dosis tepung ikan dengan menggunakan tepung kepala udang memiliki nilai protein yang menyamai pakan komersil.

Dari hasil pengamatan laju pertumbuhan menunjukkan hasil yang tidak signifikan dengan rentan pertumbuhan yang tidak jauh. Hal tersebut menunjukkan bahwa sebenarnya substitusi dosis tepung ikan menggunakan tepung kepala udang dapat menyamai 
pertumbuhan yang diberikan oleh pakan komersil. Pakan (P1) memiliki kandungan protein yang cenderung lebih tinggi dibandingkan dengan pakan komersil $(\mathrm{K})$ dan pakan perlakuan substitusi dosis tepung ikan dengan menggunakan tepung kepala udang yang lainnya.Laju pertumbuhan cenderung rendah pada perlakuan TKU lebih dari $20 \%$. Peningkatan kadar tepung kepala udang dalam pakan akan menyebabkan penurunan bobot badan dan laju pertumbuhan harian, hal ini pula terjadi pada jenis ikan yang lainnya seperti pada ikan kerapu bebek (Laining et al. 2001). Hasil riset Mukti (2012) melaporkan bahwa laju pertumbuhan tertinggi pada ikan patin terdapat pada pakan dengan dosis 30\% TKU. Sedangkan menurut Jatomea et al. (2002) mengatakan bahwa penambahan tepung kepala udang sebesar $15 \%$ dalam pakan dapat meningkatkan pertumbuhan ikan nila (Oreochromis niloticus). Hasil riset lain dari Ceballos et al (2009) menyatakan bahwa penambahan tepung kepala udang sampai dosis $25 \%$ masih memberikan hasil yang signifikan. Pada penelitian ini bahan pakan ikan yang terdiri dari tepung ikan telah disubtitusi dosisnya dengan menggunakan tepung kepala udang pada beberapa perlakuan.

Apabila dilihat dari segi ekonomi pada perlakuan subtitusi dosis tepung ikan dengan menggunakan tepung kepala udang relatif murah dan mudah diperoleh. Harga pakan komersil rata-rata $17.000-18.000$ rupiah perkilogram, dengan penggunaan tepung kepala udang dapat menekan penggunaan tepung ikan yang merupakan bahan utama yang memiliki harga yang relatif tinggi untuk bahan pembuatan pakan dengan penekanan harga sampai 6.000 - 7.000 rupiah pada P3. Hasil uji statistik menunjukkan bahwa perlakuan tidak memberikan pengaruh yang berbeda nyata atau tidak signifikan.Tidak berpengaruh nyatanya atau perlakuan substitusi dosis tepung ikan menggunakan tepung kepala udang ini karena kandungan protein yang dimiliki sama-sama dapat menunjang pertumbuhan. Selain itu kebutuhan protein pada ikan Nila yakni sebesar $25-35 \%$, sehingga secara garis besar semua perlakuan dapat menunjang kebutuhan protein ikan Nila.

Kemungkinan nilai perlakuan (P3) yang cenderung rendah pada pertumbuhan ikan Nila ini diduga karena kandungan serat kasar dan abu yang tinggi karena semakin meningkatnya penggunaan tepung kepala udang pada pakan. Berdasarkan Lampiran 6 nilai kadar abu dan serat kasar tertinggi terdapat pada pakan P3 dengan nilai serat kasar sebesar 9,61875 \% dan abu sebesar 18,2095 \% . Menurut Tillman et al (1989) dalam Pamungkas (2012), serat kasar terdiri atas selulosa, hemi selulosa, dan lignin yang sulit dicerna. Hal ini dijelaskan oleh Indriyanti (2011) menyatakan bahwa serat kasar yang tinggi akan memberikan rasa kenyang karena komposisi karbohidrat yang kompleks yang menghentikan nafsu makan sehingga mengakibatkan turunnya konsumsi pakan. Selain itu serat kasar yang tinggi juga menyebabkan porsi eksreta lebih besar dari yang lainnya sehingga penyerapan protein yang dapat dicerna semakin berkurang.

Dengan menurunnya konsumsi pakan dan penyerapan protein maka mengakibatkan laju pertumbuhan pada ikan menurun. Semakin tingginya serat kasar yang ada didalam pakan juga membuat pemberian pakan menjadi sia-sia, hal ini sejalan dengan pernyataan Piliang (2006), serat kasar membantu mempercepat ekskresi sia-sia makanan melalui sistem pencernaan, pakan dengan kandungan serat kasar yang tinggi dapat menyebabkan absorbsi zat makanan berkurang dan koefisien cerna semua zat makanan menurun. 
Tingginya kandungan serat kasar dalam tepung kepala udang disebabkan karena adanya kitin. Shiau Yu (1999) dalam Jatomea et al (2000) mengatakan bahwa kitin mempunya dampak yang kurang baik terhadap pertumbuhan dan rasio konversi pakan pada ikan nila. Hetramf dan Piedad-Pscual (2000) melaporkan bahwa kadar kitin dalam tepung kepala udang berbeda-beda tergantung cara pengolahannya.

\section{Efisiensi Pakan}

Efisiensi pakan merupakan rasio antara pertambahan bobot tubuh dengan pakan yang diberikan selama pemeliharaan Tacon (1987) dalam Amarwati et al (2015).Efisiensi pakan dapat dilihat melalui beberapa faktor yakni salah satunya adalah rasio konversi pakan.Rasio konversi pakan adalah perbandingan antara jumlah pakan yang dikonsumsi dengan penambahan berat badan ikan yang dihasilkan.NRC (1993) menjelaskan bahwa besar kecilnya rasio konversi pakan dipengaruhi oleh beberapa faktor tetapi yang terpenting adalah kualitas dan kuantitas pakan, spesies, ukuran dan kualitas air.Besar kecilnya rasio konversi pakan menentukan efektivitas pakan tersebut. Dari hasil penelitian yang telah dilakukan bahwa nilai konversi pakan menunjukkan jika pakan mempunyai kualitas yang sama baiknya untuk pertumbuhan ikan nila. Berdasarkan Gambar.6 diketahui bahwa pakan komersil, pakan tanpa penggunaan TKU, dan pakan dengan penggunaan TKU dalam substitusi dosis tepung ikan memberikan pengaruh tidak berbeda nyata terhadap nilai konversi pakan namun memiliki nilai FCR yang baik yakni dengan kisaran 1,348 - 1,498. Menurut Kordi (2010) dalam Sandri dan Yusni (2018), nilai FCR cukup baik berkisar 0,8-1,6. Semakin rendahnya nilai FCR maka kualitas pakan yang diberikan semakin baik.Dari hasil analisis yang telah dilakukan, pakan buatan yang diberikan mempunyai kualitas yang cukup baik, karena pakan yang diberikan benarbenar dapat dimanfaatkan oleh ikan untuk menunjang pertumbuhan bobot ikan Nila. Menurut Keputusan Menteri Perikanan dan Kelautan (2009) dalam Sandri dan Yusni (2018), nilai FCR ikan nila dengan ukuran 3-12 cm memiliki standar FCR 1,2-1,38\%.

\section{Kelangsungan Hidup}

Kelangsungan hidup atau survival rate (SR) adalah persentase ikan uji yang hidup pada akhir masa pemeliharaan dari total jumlah ikan uji yang ditebar pada saat pemeliharaan dalam satu wadah. Berdasarkan hasil penelitian Gambar.5 menunjukkan bahwa penggunaan TKU sebagai substitusi dosis tepung ikan ke dalam pakan ikan memberikan pengaruh yang tidak berbeda nyata terhadap tingkat kelangsungan hidup (SR) pada ikan uji $(\mathrm{P}>0,05)$ dengan kisaran nilai $88-96 \%$ dengan kategori tergolong baik selama pemeliharaan.Adapun penyebab kematian ikan adalah stress yang disebabkan masalah pada instalasi manajemen kualitas air yaitu matinya aerator karena pemadaman listrik, sehingga DO pada wadah menuruh, suhu meningkat, dan metabolism meningkat yang menyebabkan ikan menjadi setress. Menurut Mulyani et al (2014), menyatakan bahwa tingkat kelangsungan hidup $\geq 50 \%$ tergolong baik, kelangsungan hidup $30-50 \%$ sedang, dan kurang dari $30 \%$ tidak baik. Kematian ikan selama penelitian disebabkan ikan mengalami stress. Selain itu ikan mengalami stress karena pada pemeliharaan dilakukan pergantian air. Menurut Fatimah (1992) dalam Mulyani et al (2014) menyatakan bahwa kelangsunngan hidup ikan sangat bergantung pada daya adaptasi ikan terhadap makanan dan lingkungan, status 
kesehatan ikan, padat tebar, dan kualitas air yang cukup mendukung. NRC (1983) menyatakan bahwa kelangsungan hidup ikan terutama dipengaruhi oleh sifat fisika kimia media pemeliharaan dan kualitas pakan. Secara langsung maupun tidak langsung kualitas air mempengaruhi pertumbuhan dan tingkat kelangsungan hidup ikan.

\section{Kualitas Air}

Beberapa parameter kualitas air yang telah diamati memiliki kisaran yang layak untuk kelangsungan hidup ikan nila. Hasil pengukuran kualitas air selama pemeliharaan dapat dikatakan baik dan layak untuk pemeliharaan ikan nila dengan kisaran yang optimum dapat dilihat pada Lampiran 13. Berdasarkan Tabel 4 suhu pada media pemeliharaan memiliki kisaran antara 28,9 - 30,1 ${ }^{\circ} \mathrm{C}$, kisaran ini masih berada pada kisaran yang wajar untuk pemeliharaan ikan, hal ini sesuai dengan pendapat Rahardi (1996), bahwa syarat media hidup ikan adalah berkisar antara $25-30^{\circ} \mathrm{C}$ dengan perbedaan suhu antara siang dan malam hari tidak lebih dari $5^{\circ} \mathrm{C}$. Nilai derajat keasaman $(\mathrm{pH})$ selama pemeliharaan berkisar antara 7,1-7,7. Menurut Amri (2003) derajat keasaman yang dapat ditoleransi oleh ikan nila yakni dengan nilai kisaran 5-9. Kandungan oksigen terlarut (DO) selama pemeliharaan memiliki kisaran antara 5-6,2mg/L. Oksigen terlarut dalam air adalah faktor yang sangat kritis dalam pemeliharaan. Menurut Amri (2003) bahwa kandungan oksigen terlarut dalam air yang baik untuk budidaya ikan minimal $4 \mathrm{mg} / \mathrm{L}$.

\section{Kesimpulan}

Adapun kesimpulan
didapatkan dari penelitian ini
tepung kepala udang sebagai bahan
substitusi dosis tepung ikan pada pakan
ikan Nila menunjukkan hasil yang tidak berbeda nyata atau tidak signifikan. Masing-masing substitusi dosis tepung ikan dengan menggunakan tepung kepala udang, maupun pakan tanpa substitusi dosis dapat sama-sama menunjang pertumbuhan ikan Nila

\section{Daftar Pustaka}

Abun. 2009. Pengolahan limbah udang windu secara kimiawi dengan $\mathrm{NaOH} \quad$ danH$_{2} \mathrm{SO}_{4} \quad$ terhadap protein dan mineral terlarut. Makalah Ilmiah. JurusanNutrisi dan Makanan Ternak Fakultas Peternakan UniversitasPadjadjaran.Jatinan gor.

Afrianto, E. Dan Liviawaty, E. 2005. Pakan Ikan Dan Perkembangannya. Kanisius, Yogyakarta.

Amarwati, H dkk. 2015. Pemanfaatan Tepung Daun Singkong (Manihot utilissima) Yang Difermentasi Dalam Pakan Buatan Terhadap Pertumbuhan Benih Ikan Nila Merah (Oreochromis niloticus). Journal of Aquaculture Management and Technology. $4(2): 51-59$.

Amri, K. dan Khairuman. 2003. Budidaya Ikan Nila Secara Intensif. PT.Agromedia Pustaka. Jakarta.

Badan Pusat Statistik. 2011. Statistik Kelautan dan Perikanan. Pusat Data Statistik dan Informasi (Pusdatin) Kementrian Kelautan dan Perikanan, Jakarta 
Ceballos,B. J et al. 2009. Effect of Shrimp Head Meal Inclusion Level in Litopenaeus schmitti Juveniles Diet. Rev. Invest. Mar. 30(1): 71-78.

Cholik, F., A.G. Jagatraya, R.P. Poernomo \& A. Jauzi. 2005. Akuakultur:Tumpuan Harapan Masa Depan Bangsa. Masyarakat Perikanan Nusantaradan Taman Akuarium Air Tawar TMII. Jakarta.

Ghufran, 2009.Budidaya Perairan. Buku Kedua. Bandung: PT. Citra AdityaBakti.

$$
\begin{gathered}
\text { Harrysu, 2012. Budidaya Ikan } \\
\text { Nila. Kasinius: Yogyakarta }
\end{gathered}
$$

Hayati, N. dkk.2017. Pemanfaatan Jamur Yeast (Candida utilis) Dalam Ransum Pakan Buatan Terhadap Potensi Protein Dan Retensi Energi Pada Ikan Nila (Oreochromis niloticus).

Hetramf, J.W. and Piedad Pscual. 2000. Handbook on Ingredients forAquaculture Feeds. Kluwer Academic Publisher, Netherlands.

Indriyanti Nur. 2011. Evaluasi Kecernaan Campuran Bungkil Isi Kelapa Sawit dan Onggok Yang Difermentasi Oleh Trichoderma harzianum rifai Untuk Pakan Ikan Nila (Oreochromis niloticus) [Tesis].Program Pascasarjana. Institut Pertanian Bogor, Bogor.
Iskandar, R. dan Elfaridah. 2015. Pertumbuhan Dan Efisiensi Pakan Ikan Nila (Oreochromis niloticus) Yang Diberi Pakan Buatan Berbasis Kiambang. ZIRAA'AH. 40 (1): 18-24.

Jatomea, M. P., M. A. O. et al. 2002. Feasibilility of fishmeal replecment by shrimp head silage protein hydrolysate in nile tilapia (Oreochromis niloticus) diets. Journal of Scinece of Food and Agriculture 82: 753-759.

Laining, A., Rachmansyah, Ahmad, \& Williams, K. 2003. Apparent disgesbility of selected feed ingredients for humpback grouper, Cromileptes altivelis. Aquaculture, 218:529-538

Lukman, dkk. 2014. Efektifitas Pemberian Akar Tuba (Derris elliptica) Terhadap Lama Waktu Kematian Ikan Nila (Oreochromis niloticus). Jurnal Pertanian. 5 (1): 22-31.

Mulyani, Y.S dkk. 2014. Pertumbuhan Dan Efisiensi Pakan Ikan Nila (Oreochromis niloticus) Yang Dipuasakan Secara Periodik. Jurnal Akuakultur Rawa Indonesia. 2(1) : 01-12.

Niode, A.R dkk. 2016. Pertumbuhan dan Kelangsungan Hidup Benih Ikan Nila (Oreochromis niloticus) Pada Pakan Buatan Yang Berbeda.

Palinggi dan Usman., 2011. Pengaruh Pemberian Tepung Kepala Udang Dalam Pakan Ikan 
Baronang (Siganus gutatus). Balai Riset Perikanan Air Payau.

Palinggi, dkk. 2010. Pengaruh Kadar Protein Dan Lemak Pakan Terhadap Pertumbuhan Dan Komposisi Badan Ikan Kerapu Macan (Epinephelus fuscogutatus). J. Ris. Akuakultur.5 (2) : 277-286

Pamungkas W. 2012. Aktivitas Osmoregulasi, Respons Pertumbuhan, dan Energetic CostPada Ikan Yang Dipelihara Dalam Lingkungan Bersalinitas. Jurnal Akuakultur. 7(1): 44-51.

Retno, C.M. 2012. Penggunaan Tepung Kepala Udang Sebagai Bahan Subtitusi Tepung Ikan Dalam Formulasi Pakan Ikan Patin (Pangasianodon hypophtalamus).

Sandri, T.D., dan Yusni E. 2018. Pengaruh Campuran Tepung Kepala Udang Pada Pakan Komersil Terhadap Pertumbuhan Ikan Nila (Oreochromis niloticus).

Sucipto, A dan Prihartono.(2005). Pembesaran Nila Merah Bangkok. Penebar Swadaya.Jakarta.

Sukandi, U.2003. Membuat Pakan Ikan Konsumsi. Agromedia Pustaka.Tangerang.

Suprayudi, M. A. 2010. Bahan baku lokal: Tantangan dan harapan akuakulturmasa depan. Abstrak.Simposium Nasional Bioteknologi
AkuakulturIII.IPB

International Convention Center, Bogor, Oktober 2010. 31.

Widiyati,A dan M. T. D. Sunarno. 2010. Dampak penggunan pakan buatanterhadap keberlanjutan perikanan budidaya di perairan waduk .Badanresearch kelautan dan perikanan. Bogor.

Wiryanta, B.T.W dkk. 2010. Budidaya dan Bisnis Ikan Nila. PT Agromedia. Pustaka. Jakarta. Universitas Sumatera Utara.

Yulan, A dkk. 2013. Tingkat Kelangsungan Hidup Benih Ikan Nila Gift (Oreochromis niloticus) Pada Salinitas Yang Berbeda.

Zuraidah,dkk. 2013. Pertumbuhan dan Kelangsungan Hidup Benih Ikan Nila (Oreochromis niloticus) Pada Beberapa Konsentrasi Tepung Daun Jaloh (Salix tetrasperma) Dalam Pakan. Depik 2 (1): 1619. 